\title{
To What Extent Does The Paralympic Games Promote The Integration Of Disabled Persons Into Society?*
}

\section{Chui Ling Goh**}

Every four years, the Paralympic Games (both the Summer and Winter editions) showcase the sporting performances of disabled persons. The Paralympic Movement has strived to promote the inclusion of disabled persons into society through sports, but the endeavours of the Paralympic Games are limited due to various features of the said Games, from the limitations of disability classification at the Paralympic Games, the increasing prominence of technology in disability sports, to the inapt media portrayal and 'supercrip' campaigning at the Paralympic Games. The Paralympic Games, as a separate sporting event from the Olympic Games, also exacerbate and reinforce the medical perception of disabilities in society.

This paper discusses the extent to which the Paralympic Games has promoted the inclusion of disabled persons into society through sports, in light of the human rights framework found in the Convention of the Rights of Persons with Disabilities and other core international human rights treaties. This paper will conclude that while the Paralympic Games is limited in its endeavours, the said Games does promote sports for disabled persons as an ideal and an endeavour as an elite sport for disabled person, as part of the Paralympic Movement, as well as espouse the enjoyment of fundamental rights and freedom for disabled persons in society. This paper will also proffer recommendations which can be embarked upon to promote better inclusion of disabled persons into society through the Paralympic Games.

KEYWORDS: The Paralympic Games, The Paralympic Movement, Human Rights, Convention of the Rights of Persons with Disabilities, CRPD, Disability Human Rights

\section{Introduction}

Aimee Mullins, a multi Paralympic Games medallist at the 1996 Atlanta Paralympic Games ${ }^{1}$, once commented, 'There is indeed a 'less than' association with the Paralympics. It's why I always say that I'm an Olympian and dare anyone implicitly to say that I'm not, because to do so would only be to 'qualify' my athletic achievements rather than acknowledge them in the same pantheon as that of an Olympic achievement '2. While Mullin's statement highlights the undercurrents of 'disablism,3 amongst high-performing elite athletes with disabilities, the statement highlights the absence of

\footnotetext{
* This is a post-peer-review, pre-copyedit version of an article published in the International Sports Law Journal - To What Extent Does The Paralympic Games Promote The Integration Of Disabled Persons Into Society? (2020) International Sports Law Journal 36. The final authenticated version is available online at : http://dx.doi.org/10.1007/s40318-020-00164-w.

** Graduate Researcher, Melbourne Law School, University of Melbourne. This research leading to the publication of this article was undertaken in the author's capacity as a Melbourne Law Masters student, in 2019 run of the subject, Disability Human Rights Law, under the guidance of Associate Professor Anna ArsteinKerslake.

${ }^{1}$ The Paralympic Games in 1996 was held in Atlanta, USA.

${ }^{2}$ Brittain and Wolff (2007).03/03/2021 03:48:00

${ }^{3}$ Disablism is a term conceived by Miller, Parker, and Gillison, which describes the 'discriminatory, oppressive or abusive behaviour arising from the belief that disabled people are inferior to others'. See Miller et al. (2004).
} 
equal treatment between disabled elite athletes and non-disabled elite athletes, despite the parallel nature of the Olympic Games and the Paralympic Games.

In general, there is a lack of interest in the Paralympic Games and disability sport in society, and even among researchers. Despite the emerging and flouring research arena of the Olympic Games and sports, there is a profound lack of research and academic writing on the Paralympic Games and disability sports ${ }^{4}$.

The Paralympic Games is a major international sporting event which features athletes with certain physical disabilities. The Paralympic Games, which consist of both the Summer and Winter Games, is held every four (4) years, in conjunction with the Summer and Winter Olympic Games. Host countries of the Olympic Games, which is the equivalent sporting competition for non-disabled athletes, are mandated to host the Paralympic Games ${ }^{5}$. Since its establishment and its predecessor games ${ }^{6}$ (the Stoke Mandeville Games), the Paralympic Games have strived to promote the empowerment of disabled persons ${ }^{7}$ and their participation in sports. At its inception, the Stoke Mandeville Games was intended to be a part of a rehabilitation process of injured war veterans of World War II in Britain ${ }^{8}$. The said Games has developed to include higher participation of disabled persons in the various disability sports at higher levels of performances, reinforcing the fundamental rights and freedom of disabled persons to participate in elite sports.

However, the Paralympic Games, as a separate sporting event from the Olympic Games, has not been entirely successful in promoting the participation of disabled athletes in light of certain issues on the classification of disability at the said Games, as well as the non-recognition of certain disabilities at the Paralympic Games. The increasing role of technology in disability sports and the 'cyborgfication' of disabled athletes have also diluted the recognition of disabled person as elite athletes, as there are prevalent theories that the present media attention on the Paralympic Games is primarily based on the advancement of prosthetic medicine and the creation of 'cyborgs'. Host countries have also resorted to 'supercrip' campaigning and other inapt media portrayal to market and promote the Paralympic Games, which has the effect of reinforcing socially-constructed stereotypical perception of impairment in elite disability sports.

\footnotetext{
${ }^{4}$ Brittain (2011a), p. 1.

${ }^{5}$ International Olympic Committee (2019) IOC and IPC to partner until 2032. In: International Olympic Committee. https://www.olympic.org/news/ioc-and-ipc-to-partner-until-2032. Accessed 10 June 2019.

${ }^{6}$ The Stoke Mandeville Games only ceased to occur in the early 1990s, but the games were held in conjunction with the Olympic Games from 1960.

${ }^{7}$ The term 'disabled person' (or its plural noun) shall be used throughout this article with the same meaning and connotation with 'person living with disabilities' or 'person experiencing disabilities'.

${ }^{8}$ Guttmann (1952).
} 
Nonetheless, this paper will conclude that the Paralympic Games, as part of the broader social movement within the Paralympic Movement, has positively promoted the inclusion of disabled persons into society through the recognition of the fundamental rights and freedom of disabled persons, and promoted sports to the disabled community. The Paralympic Games, as a showcase and method of advocacy of the Paralympic Movement, if seen as a means to an end, provides an elite sporting competition for disabled sports, promoting both an avenue of participation and an ideal for endeavour.

In any event, work can be done to improve the representation and participation of disabled persons at the Paralympic Games, and alleviate the dichotomy of recognition between an elite athlete with disabilities and other elite athletes, such as eradicating the prevailing social construct of disability for elite disabled athletes.

\section{The Paralympic Movement and Disability Human Rights Movement}

The Paralympic Games is often viewed as the "jewel on the crown" of the Paralympic Movement, like how the Olympic Games is to the Olympic Movement ${ }^{9}$. The Paralympic Movement ${ }^{10}$ was founded in the mid-twentieth century by the establishment of the first sporting competition for disabled persons, the Stoke Mandeville Games. In July 1948, Sir Ludwig Guttman, a neurologist and physician, decided to organise a sporting competition ${ }^{11}$ for British World War II veterans with spinal cord injuries, as part of the rehabilitation and re-integration process of injured war veterans, as well as to change public perception of disabled persons in society ${ }^{12}$.

In 1960, the Stoke Mandeville Games was held at Rome, Italy, using the same venue as the Summer Olympic Games that year. In 1989, the International Paralympic Committee ('IPC') was set up, creating a collective voice for an advocacy movement to promote the development of Paralympic sports $^{13}$. By 2001, the International Olympic Committee ('IOC') partnered IPC to cooperate based on a 'one bid, one city' model, which entails that all host countries for the Olympic Games are to host and organise the Paralympic Games as well ${ }^{14}$.

\footnotetext{
${ }^{9}$ Brittain (2011a), p. 2.

10 Inside the Games The History of the Paralympic Movement. In: Inside the Games. http://www.insidethegames.biz/articles/1010776/the-history-of-the-paralympic-movement. Accessed 10 June 2019.

${ }^{11}$ Until 1960, the Games was was known as the Stoke Mandeville Games.

${ }^{12}$ Brittain (2011b), p. 91.

13 Tweedy and Howe (2011).

14 Historic 'One Bid, One City' agreement. In: International Paralympic Committee. https://www.paralympic.org/feature/2-historic-one-bid-one-city-agreement. Accessed 30 July 2019.
} 
The Paralympic Games is separate from two (2) other major game for disability sports, viz, the Deaflympics and the Special Olympic World Games. Unlike the Paralympic Games, the Deaflympics and the Special Olympic World Games are not held in conjunction with the Olympic Games. The Deaflympics is an IOC-sanctioned elite competition for deaf athletes, while the Special Olympic World Games is an IOC-recognised elite competition for athletes (children and adults) with intellectual disabilities. The Deaflympics ${ }^{15}$ and the Special Olympic World Games are organised apart from the Paralympic Games, by Comité International des Sports des Sourds ${ }^{16}$ ('CISS') and Special Olympics ${ }^{17}$ respectively, and are held in different years and location from the Paralympic Games.

It is prudent to note at this point that there is a category at the Paralympic Games in certain sports, for persons with intellectual disabilities diagnosed before age 18, viz, athletics, swimming, rowing and table tennis, since the 2012 Paralympic Games in London. From 1996 to 2000, the Paralympic Games featured a disability category for persons with intellectual disabilities, but the organising association, International Sports Federation for People with an Intellectual Disability, was banned after the eligibility scandal at the Paralympic Games in 2000 by the Spanish basketball team, wherein ten out of twelve of its players did not have any form of intellectual disability ${ }^{18}$. Apart from one disability category for intellectual disability, the Paralympic Games generally only feature athleticism of athletes with certain physical disabilities.

Nevertheless, this paper will focus on the Paralympic Games as a means of integrating disabled persons into society, with brief references to the Deaflympics and Special Olympics World Games.

The Paralympic Games has seen tremendous growth in participation. At the 1960 Stoke Mandeville Games, there were 400 athletes from 23 countries $^{19}$; at the 2016 Rio de Janeiro Paralympic Games, there were 4,333 athletes from 159 countries $^{20}$.

It is prudent to note that while the Paralympic Games had begun as a cultural game, it has been argued to have evolved to a sporting game, which entails high level of competition and sporting performance $^{21}$. Sir Ludwig Guttman had intended the Paralympic Games (or the Stoke Mandeville

15 Welcome! In: Deaflympics. deaflympics.com. Accessed 25 July 2019.

16 Welcome. In: International Committe of Sport for the Deaf. ciss.org. Accessed 25 July 2019.

17 Special Olympics. In: Special Olympics. https://www.specialolympics.org/. Accessed 25 July 2019.

${ }^{18}$ Darcy (2003); Davis and Ferrara (1996).

19 Inside the Games The History of the Paralympic Movement. In: Inside the Games. http://www.insidethegames.biz/articles/1010776/the-history-of-the-paralympic-movement. Accessed 10 June 2019.

${ }^{20} \operatorname{Darcy}(2018 \mathrm{a})$.

${ }^{21}$ Brittain (2011c). 
Games) to be a platform for social reintegration and changing of social perception, akin to a cultural game, with the agenda to spread social ideals and foster group identity ${ }^{22}$. Nonetheless, since its inception in 1989, a part of the IPC mission statement is to enable disabled athletes to 'achieve sporting excellence ${ }^{23}$. While the dialogue of whether the Paralympic Games is a sporting or cultural game will feature in this paper, it will not be the focus issue.

The Paralympic Movement had developed with the primary goal to drive the recognition of the fundamental right and freedom to participate in sports for disabled persons ${ }^{24}$, and this movement ran parallel to the various development goals by the United Nations. In 2006, the United Nations formally recognised sports as a means to promote economic and social advancement for all people under the adoption of General Assembly Resolution 60/9 25 Sport as a means to promote education, health, development and peace, and the establishment of the 'Sports for Development' ('S4D') Movement. The established UN Office of Sports for Development and Peace signed an agreement with the IPC to promote the value of sports as a means of development for disabled persons ${ }^{26}$.

At the same time, the UN crystallised its involvement in the global human rights movement by putting the rights of disabled persons into the International Developmental Agenda ('IDA') and adopted the Convention of the Rights of Persons with Disabilities ('CRPD') in $2006^{27}$. It was acknowledged by the UN that while the fundamental rights and freedom of every person as encapsulated in the International Bill of Human Rights ${ }^{28}$ and other major core UN treaties ${ }^{29}$ are equally applicable to disabled persons, the fundamental rights of disabled persons were not sufficient recognised by State Parties ${ }^{30}$, and there was a prevailing need to highlight and reaffirm the

${ }^{22}$ Ibid.

23 About Us. In: International Paralympic Committee. https://www.paralympic.org/the-ipc/about-us. Accessed 23 June 2019.

${ }^{24}$ Karageorgos and Higgs (2018), p. 282.

${ }^{25}$ Sports as a Means to Promote Education, Health, Development and Peace, GA Res 60/9, UN Doc A/RES/60/9 (17 January 2006, adopted 3 November 2005).

${ }^{26}$ Karageorgos and Higgs (2018), p. 273.

${ }^{27}$ Convention of the Rights of Persons with Disabilities and its Optional Protocol, GA Res 61/106, UN Doc A/RES/61/106 (30 March 2007, adopted on 13 December 2006) ('CRPD').

${ }^{28}$ The International Bill of Human Rights consist of three main documents, viz, the Universal Declaration of Human Rights, GA Res 217A(III), UN GAOR, UN Doc A/811 (10 December 1948) ('UDHR'), International Covenant on Civil and Political Rights and its Optional Protocols, GA Res 2200A(XXI), UN GAOR, UN Doc A/RES/2200 (16 December 1966, adopted on 23 March 1976) ('ICCPR'), and International Covenant of Economic, Social and Cultural Rights, GA Res 2200A(XXI), UN GAOR, UN Doc A/RES/2200 (16 December 1966, adopted on 3 January 1976) ('ICESCR').

${ }^{29}$ Other major core UN treaties include Convention on the Elimination of All Forms of Discrimination against Women, GA Res 34/180, UN Doc A/RES 34/108 (3 September 1982, adopted on 18 December 1979) ('CEDAW'), International Convention on the Elimination of All Forms of Racial Discrimination, GA Res 2106(XX) (4 January 1969, adopted on 21 December 1965), and Convention on the Rights of the Child, GA Res 44/25, UN Doc A/RES/44/25 (2 September 1990, adopted on 20 November 1989) ('CRC').

${ }^{30}$ Stein (2017), p. 5. 
fundamental rights and freedom of disabled persons in a new Convention, the CRPD. The CRPD eventually became the fastest negotiated UN Convention ${ }^{31}$, as well as the UN Convention with the highest number of signatories on its opening day on 30 March $2007^{32}$.

It is interesting to note that unlike the International Bill of Human Rights and other core UN human rights treaties, the right to participation in sports was explicitly recognised as a fundamental right which should be made available to disabled persons under the CRPD. Article 30 of the CRPD ${ }^{33}$ imposes positive obligations on State Parties to, inter alia, promote the participation of disabled persons in sports and ensure equal access to sporting and recreational activities. This right to participation in sports for disabled persons under the CRPD crystallises the prevailing human rights movement for disabled persons in sports under the Paralympic Movement.

\section{The Paralympic Games as a Means of Integration}

An elite sporting competition like the Paralympic Games provides various means of integration for disabled persons into society, from civil and political rights, to economic, social and cultural rights, although its effectiveness and scope is limited. The following paragraphs will analyse broad fundamental human rights concepts in regard to the Paralympic Games, pursuant to the CRPD framework, with specific references provided to the International Bill of Human Rights ${ }^{34}$ and other core UN human rights treaties ${ }^{35}$.

At the outset, it is prudent to highlight again that the CRPD contains an explicit right for disabled persons to participate in sports. Article $30(5)$ of the CRPD $^{36}$ imposes positive obligations on State

31 Convention on the Rights of Persons with Disabilities (CRPD) | United Nations Enable. https://www.un.org/development/desa/disabilities/convention-on-the-rights-of-persons-with-

disabilities.html\#Fulltext. Accessed 1 June 2019.

${ }^{32}$ Ibid.

${ }^{33}$ Convention of the Rights of Persons with Disabilities and its Optional Protocol, GA Res 61/106, UN Doc A/RES/61/106 (30 March 2007, adopted on 13 December 2006) ('CRPD').

${ }^{34}$ The International Bill of Human Rights consist of three main documents, viz, the Universal Declaration of Human Rights, GA Res 217A(III), UN GAOR, UN Doc A/811 (10 December 1948) ('UDHR'), International Covenant on Civil and Political Rights and its Optional Protocols, GA Res 2200A(XXI), UN GAOR, UN Doc A/RES/2200 (16 December 1966, adopted on 23 March 1976) ('ICCPR'), and International Covenant of Economic, Social and Cultural Rights, GA Res 2200A(XXI), UN GAOR, UN Doc A/RES/2200 (16 December 1966, adopted on 3 January 1976) ('ICESCR').

${ }^{35}$ Other major core UN treaties include Convention on the Elimination of All Forms of Discrimination against Women, GA Res 34/180, UN Doc A/RES 34/108 (3 September 1982, adopted on 18 December 1979) ('CEDAW'), International Convention on the Elimination of All Forms of Racial Discrimination, GA Res 2106(XX) (4 January 1969, adopted on 21 December 1965), and Convention on the Rights of the Child, GA Res 44/25, UN Doc A/RES/44/25 (2 September 1990, adopted on 20 November 1989) ('CRC').

${ }^{36}$ Convention of the Rights of Persons with Disabilities and its Optional Protocol, GA Res 61/106, UN Doc A/RES/61/106 (30 March 2007, adopted on 13 December 2006) ('CRPD'). 
Parties to participation in sporting activities, inter alia, ensuring access to sporting venues and services, ensuring the opportunities to organise and develop disability-specific sporting activities.

The Paralympic Games provides a platform for the showcase of elite sporting performance in disability-specific sports and activities, and buttresses the right of disabled persons to participate in sporting activities, pursuant to article $30(5)$ of the CRPD $^{37}$. Specifically, the Paralympic Games affords the opportunity to disabled persons to participate and compete in 'disability-specific' sporting activities, as stipulated under article 30(5)(b) of the CRPD.

Sporting activities under the Paralympic Games have developed to be more disability-specific. There are two main types of disability-specific sports under the Paralympic Games, viz, sports which have been adapted for disability (herein after known as 'Adapted Disability Sports'), and new disability sports i.e. sports which have been created for disability (hereinafter known as 'New Disability Sports'). Examples of Adapted Disability Sports activities are beep baseball ${ }^{38}$, and the various disability classification categories in both athletics ${ }^{39}$ and swimming ${ }^{40}$. Examples of New Disability Sports activities are boccia ${ }^{41}$ and goalball ${ }^{42}$.

Having such disability-specific sports on elite sporting level like the Paralympic Games indirectly removes barriers against participation by virtue of any lack of opportunities, and inexorably creates an ecosystem of disability sports in the participating and host countries, starting with political interests, infrastructure and investment, culminating in participation at the Paralympic Games. Investment in disability sports and development of sports policies with the intention of participation at the Paralympic Games will generate a domestic sporting ecosystem to promote development and participation in disability sports. This can be briefly analysed in light of the oft-cited nine-pillar

\footnotetext{
${ }^{37}$ Ibid.

${ }^{38}$ Beep baseball is an adapted form of baseball for visually-impaired athletes, using a ball that beeps. See The Official Site of the National Beep Baseball Association|NBBA.org Homepage. https://nbba.org/. Accessed 29 July 2019.

${ }^{39}$ There are various disability classification for athletics at the Paralympic Games, from visual impairment to intellectual impairment, to physical impairment. Within each impairment, there are various class of disability for competition, based on the mode of competition (the use of wheelchair or throwing frame) and extent of disability. See World Para Athletics Classification \& Categories. https://www.paralympic.org/athletics/classification. Accessed 29 July 2019; (2018) World Para Athletics Rules and Regulations (2018-2019).

40 There are various disability classification for swimming at the Paralympic Games, from visual impairment to intellectual impairment, to physical impairment. Within each impairment, there are various class of disability for competition, based on the strokes type and sports class. See World Para Swimming Classification \& Categories - SB9, SM8. In: International Paralympic Committee. https://www.paralympic.org/swimming/classification. Accessed 29 July 2019.

${ }^{41}$ Boccia is a game at the Paralympic Games similar to bowls and pentaque, wherein the ball is thrown or rolled to the white target ball, jack. See Boccia - Paralympic Athletes, Photos \& Events. In: International Paralympic Committee. https://www.paralympic.org/boccia. Accessed 25 June 2019.

${ }^{42}$ Goalball is a game at the Paralympic Games for visually-impaired athletes. With a ball with bells embedded within it, players throw the ball into the opponent's goal. See Goalball - Paralympic Athletes, Photos \& Events. In: International Paralympic Committee. https://www.paralympic.org/goalball. Accessed 25 June 2019.
} 
SPLISS framework by De Bossche ${ }^{43}$, viz, financial support, elite sport policies (with governance, organisation and structure), opportunities for sporting participation for children, identification of young talented athletes, athletes' living standards and training support, elite sport facilities and infrastructure, quality and quantity of coaches, access to national and international competitions, scientific support and research. When state government intends to send participants to the Paralympic Games, the various SPLISS pillars for disability sports will be necessarily built and buttressed. For example, there will be investment into coaching education, identification of young talented athletes, development in training and sports science support for the identified disabled athletes, rise in training and living standards, creating an ecosystem for high performance athletes at the Paralympic Games. This cycle will generate greater participation in both disability-specific sports, mainstream sporting activities, creating an even greater level of sports participation among disabled persons. In particular, such an ecosystem will also provide children with disabilities access to sporting activities, pursuant to article $30(5)(\mathrm{d})$ of the $\mathrm{CRPD}^{44}$.

As the Paralympic Games continues to increase ${ }^{45}$ in scope and participation, more political interests and resources can be expected to be generated out of the participating and hosting countries, therefore further fostering the right of disabled persons to 'organise, develop and participate' in sporting activities, pursuant to article $30(5)(\mathrm{b})$ of the $\mathrm{CPRD}^{46}$.

Participation in disability-specific activities can also include partaking in the Paralympic Games by way of spectating. Hosting contracts of Paralympic Games (and the Olympic Games) by the host countries include a clause to ensure that all venues at the said Games are 'fully accessible 47 . Most host countries are awarded the bid to be host cities of the Paralympic Games and the Olympic Games based on their proposals on accessibility and infrastructure development ${ }^{48}$. Apart from live participation (by way of spectating) of the Paralympic Games at the host countries, IPC mandates accessible forms of Games-time publications, such as Braille, captioning, and colour-contrasting ${ }^{49}$. Without a doubt, the Paralympic Games promote participation in disability-specific sporting

\footnotetext{
${ }^{43}$ De Bosscher et al. (2006).

${ }^{44}$ Convention of the Rights of Persons with Disabilities and its Optional Protocol, GA Res 61/106, UN Doc A/RES/61/106 (30 March 2007, adopted on 13 December 2006) ('CRPD').

${ }^{45}$ Since the Paralympic Games in 1960 to 2012, there is a 1059\% increase in athletes participation and 250\% increase in number of sports. See Kerr (2018).

${ }^{46}$ Convention of the Rights of Persons with Disabilities and its Optional Protocol, GA Res 61/106, UN Doc A/RES/61/106 (30 March 2007, adopted on 13 December 2006) ('CRPD').

${ }^{47}$ International Olympic Committee (2016) Host City Contract - Principles: Games of the XXXIII Olympiad in 2024, para. $25(1)(\mathrm{c})$.

${ }^{48}$ Dickson et al. (2016).

${ }^{49}$ Laura Misener and Kristina Molloy, 'Organising and Delivering the Modern Paralympic Games: Contemporary Debates Relating to Integration and Distinction' in The Palgrave Handbook of Paralympic Studies (Palgrave Macmillan) 197, 212.
} 
activities (pursuant to article 30(5)(b) of the $\mathrm{CRPD}^{50}$ ) and access to sporting activities (pursuant to article 30(5)(e) of the $\mathrm{CRPD}^{51}$ ) by providing the facilities and opportunities for disabled persons to watch the Paralympic Games.

It is prudent to note at this point that the first ever declaration of the fundamental rights and liberties of athletes in sport, the Universal Declaration of Player Rights ('UDPR'), was published by the World Players' Association, the global voice for organised players in the governance of world sports, on 14 December $2017^{52}$, as part of the ongoing support against human rights violation in sports ${ }^{53}$. Although the UDPR was published as a guideline, it embodies fundamental human rights and freedom found in other core human right treaties and the UDHR. It is also arguable that the UDPR crystallised accepted international norms on the rights of athletes and/or players, which ought to be recognised for disabled athletes as well. In particular, article 3 of the $\mathrm{UDPR}^{54}$ embodies the principle of equality to be enjoyed by all players, without discrimination based on disability.

\subsection{The Rights of Equality and Non-Discrimination at the Paralympic Games}

Article 5 of the CRPD ${ }^{55}$ highlights one of the most fundamental human rights of all persons equality and non-discrimination - which are comprehensively embodied in the International Covenant on Civil and Political Rights ('ICCPR') ${ }^{56}$ and the International Covenant of Economic, Social and Cultural Rights ('IESCR') 57 . Both the ICCPR and the IESCR encapsulates an open list of grounds which State Parties should do to promote equality and eliminate discrimination, and this fundamental right of equality is centred upon the concept of human dignity and inherent worth, as proclaimed in articles 1 and 2 of the Universal Declaration of Human Rights ('UDHR') 58 . Arguably,

${ }^{50}$ Convention of the Rights of Persons with Disabilities and its Optional Protocol, GA Res 61/106, UN Doc A/RES/61/106 (30 March 2007, adopted on 13 December 2006) ('CRPD').

${ }^{51}$ Ibid.

52 World Players Association launches Universal Declaration of Player Rights | UNI Global Union. https://www.uniglobalunion.org/news/world-players-association-launches-universal-declaration-player-rights. Accessed 9 June 2019.

${ }^{53}$ Kaiser M A guide to the World Players Association's Universal Declaration of Player Rights. In: LawInSport. https://www.lawinsport.com/topics/sports/item/a-guide-to-the-world-players-association-s-universaldeclaration-of-player-rights. Accessed 22 July 2019.

${ }^{54}$ World Players Association (2017) Universal Declaration of Player Rights.

${ }^{55}$ Convention of the Rights of Persons with Disabilities and its Optional Protocol, GA Res 61/106, UN Doc A/RES/61/106 (30 March 2007, adopted on 13 December 2006) ('CRPD').

${ }^{56}$ International Covenant on Civil and Political Rights and its Optional Protocols, GA Res 2200A(XXI), UN GAOR, UN Doc A/RES/2200 (16 December 1966, adopted on 23 March 1976) ('ICCPR').

${ }^{57}$ International Covenant of Economic, Social and Cultural Rights, GA Res 2200A(XXI), UN GAOR, UN Doc A/RES/2200 (16 December 1966, adopted on 3 January 1976) ('ICESCR').

${ }^{58}$ Universal Declaration of Human Rights, GA Res 217A(III), UN GAOR, UN Doc A/811 (10 December 1948) ('UDHR'). 
the right to equality and non-discrimination forms the cornerstone of other fundamental human rights under the International Bill of Human Rights, and the CRPD ${ }^{59}$.

Equality as a concept is repeated across the other fundamental rights in the $\mathrm{CRPD}^{60}$. In the General Comment Number $6^{61}$ on article 5 of the CRPD, the UN Committee of the Rights of Persons with Disabilities clarified that the CRPD is based the new concept of 'inclusive equality ${ }^{\prime 62}$, an equality concept beyond substantive equality ${ }^{63}$ based on redistribution, recognition, participation, and accommodation.

Discrimination in the CPRD and other human rights instrument generally refers to both direct and indirect discrimination. Direct discrimination under the CRPD pertains to situations at which disabled persons are treated in a less favourable manner than other persons due to 'a different personal status in a similar situation for a reason related to a prohibited ground ${ }^{64}$. On the other hand, indirect discrimination under the CRPD refers to any 'laws, policies or practices' which have a 'disproportionate negative impact' on a disabled person ${ }^{65}$. This is especially so when the status of disabled persons prevents them from benefitting from the opportunity ${ }^{66}$. In article 5(3) of the CRPD, there is a positive obligation on State Parties to address both direct and indirect discrimination.

It is interesting to note that article 5(3) of the CRPD intentionally couples the concepts of equality and non-discrimination with 'reasonable accommodation'. Under General Comment 3, the UN Committee of the Rights of Persons with Disabilities explained ${ }^{67}$ that any forms of 'denial' of reasonable accommodation constitutes disability-based discrimination, and contravenes article 5 of the CRPD. Admittedly onerous, this inclusion of reasonable accommodation places a positive obligation on State Parties to take specific measures to achieve 'de facto equality' for disabled

${ }^{59}$ Convention of the Rights of Persons with Disabilities and its Optional Protocol, GA Res 61/106, UN Doc A/RES/61/106 (30 March 2007, adopted on 13 December 2006) ('CRPD').

${ }^{60}$ Ibid.

${ }^{61}$ Committee on Rights of Persons with Disabilities, General Comment No. 6 (2018) on Equality and Nondiscrimination (Article 5 of the Convention of the Rights of Persons with Disabilities), UN CRPDOR, $19^{\text {th }}$ sess, UN Doc CRPD/C/GC/6 (26 April 2018) ('General Comment 6').

${ }^{62}$ Ibid, para. 11.

${ }^{63}$ Substantive Equality is a concept which endeavours to address 'structural and indirect' discrimination. See Committee on Rights of Persons with Disabilities, General Comment No. 6 (2018) on Equality and Nondiscrimination (Article 5 of the Convention of the Rights of Persons with Disabilities), UN CRPDOR, $19^{\text {th }}$ sess, UN Doc CRPD/C/GC/6 (26 April 2018) ('General Comment 6').

${ }^{64}$ Ibid, para. 18(a).

${ }^{65}$ Ibid, para. 18(b).

${ }^{66}$ Ibid.

${ }^{67}$ Ibid, para. 17. 
persons so that they can enjoy all human rights and fundamental freedoms 'on an equal basis with others ${ }^{68}$.

In assessing the Paralympic Games' effectiveness as a tool to promote equality and nondiscrimination, it is prudent to consider whether reasonable accommodations were made, pursuant to the CRPD. Paralympic sports consist of new sporting events created for disabled athletes, as well as significant modifications to mainstream sporting activities to accommodate various disabilities. In determining whether the accommodations afforded were reasonable, its relevance, appropriateness and effectiveness ${ }^{69}$ must be assessed. The UN Committee on the Rights of Persons with Disabilities listed out certain factors which ought to guide the provision of reasonable accommodation, inter alia, whether the accommodation is 'legally and materially possible' (i.e. feasibility $)^{70}$, whether the accommodation is 'relevant' or 'effective in ensuring the realisation of the right in question ${ }^{, 71}$, whether the modification imposes a 'disproportionate or undue burden, 72 on the duty bearer, and whether the reasonable accommodation is suitable based on factors such as costs, resources, 'reasonable health and safety requirements' ${ }^{73}$.

The Paralympic Games, as an elite sporting competition conducted parallel to the Olympic Games, may very well be the pinnacle of achieving equality and non-discrimination in terms of sports participation opportunities for its participants. In its milestone partnership with the IOC in 2001, the Paralympic Games have been held in conjunction with the Olympic Games, thereby giving the Paralympians the same opportunity to participate in an elite sporting competition in association with the Olympic prestige. Like athletes at the Olympic Games, athletes at the Paralympic Games are the top athletes of their event, battling for a place on the same podium as the athletes at the Olympic Games, and subjected to similar sporting rules and regulations, such as the World Anti-Doping Code $^{74}$. Disabled sports is no longer just an exhibition event ${ }^{75}$ at the Olympic Games, but one that has full medal status at the Paralympic Games.

As an example of reasonable accommodation in sports, the Paralympic Games has been developed to be competed in classifications based on extent of impairment, with para-athletics as the sport with the greatest number of classifications and events. The Paralympics Games is based on a functional classification method, with the intention of promoting participation by 'minimising the impact of

\footnotetext{
${ }^{68}$ Ibid.

${ }^{69}$ Ibid, para. 25(a).

${ }^{70}$ Ibid, para. 26(b).

${ }^{71}$ Ibid, para. 26(d).

${ }^{72}$ Ibid, paras. 25(b), 26(d).

${ }^{73}$ Ibid, para. 26(e).

74 World Anti-Doping Agency (2015) World Anti-Doping Code.

${ }^{75}$ Legg et al. (2009).
} 
eligible types of impairment on the outcome of competition ${ }^{, 76}$. The classification at the Paralympic Games is undertaken to ensure that an athlete's impairment is relevant to sport performance, and also to ensure that the athletes compete in an equitable manner with other athletes ${ }^{77}$. From the first and only wheelchair archery event in the predecessor of the Paralympic Games in 1948, the Paralympic Games has developed to recognise more impairment types in sporting competition, such as vision impairment, impaired strength, impaired range of movement, limb deficiency, hypertonia, short stature, and intellectual impairment. By the 2016 Summer Paralympic Games, 4317 participants from 158 countries ${ }^{78}$ were given the opportunity to compete at an elite sporting competition at the same location as the 2016 Summer Olympic Games, just one month after.

However, the value of the Paralympic Games in the disability equality movement has been largely debated in its use and effectiveness. At the outset, while the strengthening of ties between the IOC and the IPC has provided the IPC with certain recognition and commercial opportunities, the IOC represents the IPC in meetings and makes the IPC seem like a 'subsidiary' or one that is 'subsumed ${ }^{79}$ under the IOC. The Paralympic Games, which is usually conducted after the Olympic Games, is often described as a concession, reflected by the lack of audience interests and appeal, and reporting enthusiasm and coverage ${ }^{80}$, which is often attributed to the perceived lack of aesthetic appeal $^{81}$ and may affect commercial and sponsorship opportunities of the Paralympic Games.

The Paralympic Games is also limited in providing equal opportunities to disabled persons, due to the limitations to the classification of disabilities at the Paralympic Games. For example, certain sports only permit participation by certain categories of impairment, such as wheelchair team sports like wheelchair rugby and wheelchair basketball, which only caters to sports for disabled persons with the ability to use a wheelchair. Such wheelchair sporting events do not allow for participation for the visually-impaired, or the hearing-impaired, or the intellectually-impaired, and there are no similar sporting events for them at the Paralympic Games. There is also currently no Paralympic event for persons with recognised mental disabilities. Furthermore, certain disability classifications are cut from the Paralympic Games, often due to lack of participants, and these cuts serve to further reduce participation and reduce competitiveness, as such athletes may not have the motivation or ability to make the qualifications standards for the higher classifications. This is high prevalent in

\footnotetext{
${ }^{76}$ Tweedy and Vanl (2009).

${ }^{77}$ International Paralympic Committee (2015) IPC Athlete Classification Code: Rules, Policies and Procedures for Athlete Classification.

${ }^{78}$ Brittain (2018a), p. 146.

${ }^{79}$ Purdue (2013).

${ }^{80}$ Golden (2003).

${ }^{81}$ Bertling and Schierl (2008).
} 
Paralympic sports such as athletics, wherein the T43, T45 and T46 categories were eliminated from the sprints events at the 2016 Summer Paralympic Games for both male and female categories.

Furthermore, not all major impairment groups have been classified or represented at the Paralympic Games. The Paralympic Games only features 'physical disabilities' such as vision impairment, impaired strength, impaired range of movement, limb deficiency, hypertonia, short stature, and intellectual impairment. Certain impairment groups such as mental health disabilities and hearing impairments are not classified as a disability impairment at the Paralympic Games. Such athletes are only afforded the opportunity to compete at separate competitions such as Special Olympics World Games and Deaflympics, and not at the Paralympic Games, which is held in conjunction with the Olympic Games.

In general, there is also lesser countries who send delegations to the Paralympic Games. At 2016 Summer Paralympic Games, only 158 countries sent a delegation ${ }^{82}$, out of the 206 National Olympic Committee recognised by the IOC. Notably, at the 2014 Sochi Winter Paralympic Games, out of the lesser 45 countries which sent a delegation ${ }^{83}$, there were none from the African continent. While there may be much to discuss about disability politics and racial intersectional discrimination of disabled persons, there is, more prominently, the undercurrents of inequality based on power and privilege ${ }^{84}$ at play in the accessibility of disability sports, especially in African countries faced with poverty, lack of technology, and lower level and pace of development ${ }^{85}$. The inequality in sports based on power and privilege is further accentuated in disability sports which is highly dependent on technology and equipment in performance.

Furthermore, in comparison to the Olympic Games, the Paralympic Games have also been portrayed to be (and treated as) a cultural game - to promote a social agenda - rather than a sporting game. This perception is often reinforced by inapt media portrayal of the Paralympic Games, which not only perpetuates the medical model of disability ${ }^{86}$ and focuses on the impairments of the individuals, it also diminishes the impact of the Paralympic Games as an equal sporting opportunity for disabled persons. In the 2012 Paralympic Games in London, there was a media pattern of supercrip ${ }^{87}$ advertising, especially with one of UK's main broadcaster, Channel 4, promoting the 'meet the

\footnotetext{
${ }^{82}$ Brittain (2018a), p. 147.

${ }^{83}$ Ibid.

${ }^{84}$ Rocco and West (1998).

${ }^{85}$ Brittain (2018b).

${ }^{86}$ The medical model of disability is a view of disability in the form of its medical impairments, in comparison to the social model of disability, which views disability as a social construct. These two models of disability were conceived together. See Oliver (1990).

87 'Supercrip' is essentially a stereotyping process, which describes disabled persons as heroes who have 'fight against [their] impairment' in order to achieve unlikely success. See Silva and Howe (2012), p.175.
} 
Superhumans ${ }^{, 88}$ campaign for the channel's coverage of the Paralympic Games. Such marketing strategies by the host countries serve to encourage viewership based on the athletes' disabilities, reinforcing the Paralympic Games as a cultural game, rather than an elite sporting competition. But more fundamentally, out of the four (4) Paralympic Values in the IPC, three (3) includes inspirational values (rather than aspirational ones) of 'courage', 'determination' and 'inspiration', which propagates the Paralympic Games more as cultural game, than a sporting game, despite (ironically) having the fourth Paralympic Value as 'equality'.

\subsection{The Right to Legal Capacity and Equal Recognition Before the Law at the Paralympic Games}

Alongside the fundamental human right to equality and non-discrimination in the CRPD is legal capacity and the right to equal recognition before the law, which is principally highlighted in article 12 of the CRPD ${ }^{89}$. Like equality and non-discrimination, legal capacity is arguably the backbone of a plethora of other human rights, as proffered by Flynn and Arstein-Kerslake ${ }^{90}$, as the nature of legal capacity affects the freedom to make one's own choices, full and effective participation in society, equality of opportunities, and even accessibility ${ }^{91}$.

Legal capacity as a concept had to be explicitly mentioned in a disability human rights instrument due to the common prevailing practice of denying the right to make decisions to persons with varying forms of mental and intellectual incapacity. It has been unequivocally explained by the UN Committee of the Rights of Persons with Disabilities that any forms of impairment or status of disability is not a ground to deny legal capacity or equal recognition before the law ${ }^{92}$.

The sporting ecosystem which is generated by the presence of the Paralympic Games within participating and host countries empowers the disabled individuals within the system as persons with the ability to live independently and make decisions, whether independently or supported. From providing opportunities for sporting participation for young disabled children and the identification of sporting talents, to the provision of adequate living standards and training support for the elite disabled athletes, and access to competitions, these high-performance policies clothe the disabled athletes within the system with dignity and legal capacity, and endows them with equal recognition before the law as elite athletes. Prominently, disabled athletes have to be provided access

\footnotetext{
${ }^{88}$ Crow (2014).

${ }^{89}$ Convention of the Rights of Persons with Disabilities and its Optional Protocol, GA Res 61/106, UN Doc A/RES/61/106 (30 March 2007, adopted on 13 December 2006) ('CRPD').

${ }^{90}$ Flynn and Arstein-Kerslake (2014).

${ }^{91}$ Committee on Rights of Persons with Disabilities, General Comment No. 1 (2014) on Article 12: Equal Recognition Before the Law, UN CRPDOR, $11^{\text {th }}$ sess, UN Doc CRPD/C/GC/1 (19 May 2014) ('General Comment 1'), para. 4.

92 Ibid, para. 9.
} 
to technology and equipment in order to compete at the Paralympic Games, and these technology and equipment form part of a fully accessible environment for elite disabled athletes to live independently. This point will be discussed later at Accessibility. Another influence of the Paralympic Games on the empowerment of disabled athletes is providing them a professional career in their sporting performance, which also buttresses the right to work and employment under article 27 of the $\mathrm{CRPD}^{93}$. It could be argued that the affirmation of personhood for participating athletes brought about by the Paralympic Games, by way of social standing and sporting participation, facilitates and reinforces the concept of legal capacity for disabled persons.

On a micro level, the Paralympic Games provide disabled persons the reasons and opportunities to indulge in sporting activities, which is purported to have a positive impact on the self-esteem, and most importantly, self-efficacy of the disabled persons. It has been argued by proponents ${ }^{94}$ that society has prescribed standards within which individuals are measured, and when someone's biological make-up or function fails to meet this said standards, such persons are 'assumed to be inferior and are subject to a decrease in inclusion in society', and such perceptions of 'inferiority' are accentuated in sports, wherein physical capacities and functions are highlighted. Nonetheless, several studies ${ }^{95}$ have shown that the overall level of self-esteem of disabled athletes is not different from other athletes. Through participation in competitive disability sports, disabled persons are empowered through the 'recasting of their identity' and 'reframe[ing of their] understanding of physical impairment', and they are able to attain a sense of inclusion and belonging ${ }^{96}$. In fact, it is shown that self-efficacy, which is the athlete's belief in himself or herself that he or she can execute the necessary skills to obtain a desired outcome ${ }^{97}$, has a positive impact on the athlete's ability to live independently. For example, there is a finding that individuals who have high self-efficacy skills in quad rugby skills seem to have elevated self-efficacy towards daily living activities such as bedto-chair transfer ${ }^{98}$.

One of the more investigated areas of personhood in disability sports is the elite athlete's post-career transition. There is concern that after elite disabled athletes retire from competitive sports, like participation at the Paralympic Games, they may move quickly from their prevailing identity as an 'inspiration' to the harsher realities of disability-based discrimination ${ }^{99}$ and lack of personhood.

\footnotetext{
${ }^{93}$ Convention of the Rights of Persons with Disabilities and its Optional Protocol, GA Res 61/106, UN Doc A/RES/61/106 (30 March 2007, adopted on 13 December 2006) ('CRPD').

${ }^{94}$ Devine (1997).

${ }^{95}$ Martin (1999).; Campbell and Jones (1994).

${ }^{96}$ Swartz et al. (2018).

${ }^{97}$ Martin and Wheeler.

${ }^{98}$ Adnan et al. (2001).

${ }^{99}$ Swartz et al. (2019).
} 
This may be especially prevalent in societies where disability equality is not yet achieved or developed as a societal issue, wherein there is a 'huge gap' between how Paralympians are perceived and the rest of the disabled community ${ }^{100}$. By focusing on the sporting prowess of the disabled athletes, the Paralympic Games do not highlight the everyday living of disabled persons, which may include challenges from the prevailing societal perception of disability ${ }^{101}$ and the discrimination therein. There may be greater concern if elite disabled athletes believe that they have to be extraordinary in order to be treated, respected, or feel like a person ${ }^{102}$.

\subsection{The Right to Accessibility at the Paralympic Games}

Accessibility, a concept intrinsically linked to equality and legal capacity, refers to the provision of a physical environment and facilities to provide disabled persons equal opportunities for participation in society. Article 9 of the $\mathrm{CRPD}^{103}$ imposes on State Parties the positive obligation to identify and remove such environmental barriers, and take appropriate measures to ensure that the physical environment and facilities are made available to disabled persons to fully participate in society.

This right to an accessible environment for disabled persons under the CRPD ${ }^{104}$ is purported to arise from the fundamental right to freedom of movement as guaranteed under article 12 of the UDHR ${ }^{105}$ and article 13 of ICCPR ${ }^{106}$. The UN Committee of the Rights of Persons with Disabilities also commented that the right to access to information and communication under the CRPD stems from the fundamental right to opinion and expression, guaranteed under article 19 of the UDHR ${ }^{107}$ and article 19 of the $\mathrm{ICCPR}^{108}$.

The hosting of the Paralympic Games is generally preceded by a proposal by the host country on their plans for infrastructure for the said Games. Since 1992, even before the partnership between

${ }^{100}$ Christiansen S (2013) A year after the Paralympics attitudes to disability needs to improve | Sophie Christiansen. The Guardian.

${ }^{101}$ Social model of disability (n 84).

102 Swartz et al. (2019).

${ }^{103}$ Convention of the Rights of Persons with Disabilities and its Optional Protocol, GA Res 61/106, UN Doc A/RES/61/106 (30 March 2007, adopted on 13 December 2006) ('CRPD').

${ }^{104}$ Ibid.

${ }^{105}$ Universal Declaration of Human Rights, GA Res 217A(III), UN GAOR, UN Doc A/811 (10 December 1948) ('UDHR').

${ }^{106}$ International Covenant on Civil and Political Rights and its Optional Protocols, GA Res 2200A(XXI), UN GAOR, UN Doc A/RES/2200 (16 December 1966, adopted on 23 March 1976) ('ICCPR').

${ }^{107}$ Universal Declaration of Human Rights, GA Res 217A(III), UN GAOR, UN Doc A/811 (10 December 1948) ('UDHR').

${ }^{108}$ International Covenant on Civil and Political Rights and its Optional Protocols, GA Res 2200A(XXI), UN GAOR, UN Doc A/RES/2200 (16 December 1966, adopted on 23 March 1976) ('ICCPR'). 
IOC and IPC, potential hosts with infrastructure proposals and disability-friendly legislation have a clear advantage in the bidding process ${ }^{109}$. In the Bid Book that helped London win the bid to host the 2012 Summer Olympic and Paralympic Games, there was an intentional embedment of 'inclusive design' 110 and 'universal design'111 in the proposal ${ }^{112}$, a step that would be applauded by the UN Committee of Rights of Persons with Disabilities ${ }^{113}$.

In corollary, host countries of the Paralympic Games are mandated to develop their infrastructure to accommodate the disabled athletes and spectators. Games infrastructure such as the games village, accommodation, transport, and competition venues have to be constructed in a fully-accessible manner, for use in both the Olympic Games and the Paralympic Games. Many host countries go further in improving the accessibility of other infrastructure in the city. For example, in preparation for the 2008 Summer Olympic and Paralympic Games, the Beijing government developed its public transit venue and even tourist venues such as the Great Wall of China. Before the 2012 Olympic and Paralympic Games, the city of London developed its underground tube system to make the public transportation more accessible for its athletes and tourists ${ }^{114}$. The mayor of London had commented that the city had used the said Games to 'set new standards in the design of sporting venues' and 'transform [ed] the UK capital into one of the most accessible cities on earth'115. The Paralympic Games generally has a positive impact on the development of the accessibility in host countries.

Apart from developing the accessibility in host countries, there has been prominent development in the use of equipment and technology at the Paralympic Games, viz, the technological advances in the use of racing wheelchairs and prostheses. From the traditional wheelchair for daily living, disabled athletes can now compete in a significant number of sports on highly-developed wheelchairs for the individual sport, such as the negative camber sports wheelchairs for contact sports like wheelchair rugby and wheelchair basketball, to T-shaped wheelchairs made with lightweight carbon fibre ${ }^{116}$ for athletics racing in the categories T32 to T34 and T51 to T54. In fact,

109 Darcy (2018b).

110 The Access Committee for England, the Centre for Accessible Environments, the Disability Rights Commission and the Commission on Architecture and the Built Environment all considered and published advice and guidance that helped set out principles of inclusive design, which include 'acknowledging diversity and differences' and 'provides for flexibility in use'. See (2015) Inclusive Environments. In: Design Council. https://www.designcouncil.org.uk/what-we-do/built-environment/inclusive-environments. Accessed 25 June 2019.

${ }^{111}$ Story MF et al., The universal design file: Designing for people of all ages and abilities, 1998.

112 Equality and inclusion $\quad 2012$. https://webarchive.nationalarchives.gov.uk/20161003114655/http://learninglegacy.independent.gov.uk/theme s/equality-and-inclusion/index.php. Accessed 25 June 2019.

113 Committee on Rights of Persons with Disabilities, General Comment No. 2 (2015) on Article 9: Accessibility, UN CRPDOR, $11^{\text {th }}$ sess, UN Doc CRPD/C/GC/2 (22 May 2014) ('General Comment 2'), para 15

114 Ahmed (2013).

115 Ibid.

116 Burton et al. (2010). 
the IPC has been supporting the development of the racing wheelchair, and as a push for inclusion, the IPC partnered with a disability charity company, Motivation, in 2012 to develop and provide low-cost racing chairs in order to promote accessibility to the sport ${ }^{117}$. From the use of wooden prostheses for competition in the early edition of the Paralympic Games, amputee athletes can also now compete in mainstream sports such as sprinting and hockey with sport-specific prosthesis, such as the flex-foot blade for sprinting, which is famously worn by Oscar Pistorius ${ }^{118}$. While the IPC and other respective sporting bodies had to begin regulating the use of such technology to ensure level playing field, there is no doubt that the Paralympic Games has both reasonably accommodated and made the Games more accessible to disabled persons.

The Paralympic Games also includes new disability-specific sports, which are not sports adapted from mainstream sports but new sports, in order to make sports more accessible to disabled persons. For example, boccia ${ }^{119}$ was developed as a Paralympic sport to make more Paralympic sports accessible to persons living with cerebral palsy and other motor-skill disability. Another example is the Paralympic sport of goalball ${ }^{120}$, which is developed to make more Paralympic sports accessible to persons living with visual impairment.

On a side note, it is interesting that certain disabled athletes are, in fact, allowed to compete in the Olympic Games, subject to their ability to perform the sporting action and their meeting of the qualifying mark for the said events at the Olympic Games. Since Oscar Pistorius succeeded in his claim $^{121}$ at the Court of Arbitration for Sports ('CAS') ${ }^{122}$ to suspend the application of the International Association of Athletics Federation ('IAAF') ${ }^{123}$ competition rule on technical devices ('IAAF Competition Rule 144.2(e)') ${ }^{124}$ prohibiting him to compete, allowing him to compete in the

117 IPC Supports Design Low-Cost Racing Chair. In: International Paralympic Committee. https://www.paralympic.org/news/ipc-supports-design-low-cost-racing-chair. Accessed 25 June 2019.

${ }^{118}$ Oscar Pistorius is a double-leg amputee and had competed at both disabled and non-disabled sprints events for the 200-meters and 400-meters. He was the first disabled athlete to qualify and compete at the Olympic Games.

119 Boccia - Paralympic Athletes, Photos \& Events. In: International Paralympic Committee. https://www.paralympic.org/boccia. Accessed 25 June 2019.

120 Goalball - Paralympic Athletes, Photos \& Events. In: International Paralympic Committee. https://www.paralympic.org/goalball. Accessed 25 June 2019.

${ }^{121}$ CAS 2008/A/1480, Oscar Pistorius v/ International Association of Athletics Federation (IAAF), Award of 16 May 2008.

122 The Court of Arbitration for Sports is an international arbitral body established to adjudicate disputes related to sports through arbitration. See Casini (2011); McLaren (2000).

${ }^{123}$ International Association of Athletics Federations is the international federation governing the sport of athletics. See IAAF - International Association of Athletics Federations | iaaf.org. https://www.iaaf.org/home. Accessed 30 July 2019.

124 The IAAF Competition Rule 144.2(e) states that 'For the purposes of this Rule, the following shall be considered assistance, and are therefore not allowed: [...] (e) Use of any technical device that incorporates springs, wheels, or any other element that provides the user with an advantage over another athlete not using such a device'. See CAS 2008/A/1480, Oscar Pistorius v/ International Association of Athletics Federation $(I A A F)$, Award of 16 May 2008. 
2012 London Summer Olympic Games, it seems that there is room and access for certain disabled athletes to compete at the Olympic Games.

Nonetheless, it is prudent to note that the embodiment of technology in sports in the Paralympic Games has pervaded disability sports ${ }^{125}$ to the extent that there may be more emphasis on the technology than the athlete. Technology has always been driving force of the development and improvement of sports, but technology's influence in disability sports is even greater due to the significant use of equipment such as wheelchairs and prosthesis. Since the rising prominence of certain disabled athletes in prothesis at the Paralympic Games, such as Oscar Pistorius, disabled athletes are seen to be 'cyborgs' with performance advantages due to the embodiment of technology in their sport, rather than sportsmen or sportswomen themselves. In fact, IAAF published supporting research ${ }^{126}$ that Oscar Pistorius' prosthesis provide him a performance advantage over 'abledbodied athletes'.

The 'cyborgification' of the Paralympic Games, which is the media's focused attention on the advancement of prothesis technology, has inescapably diluted the value of being a disabled athlete and the impact of the Paralympic Games as a means of the integration of disabled persons. The Paralympic Games has been celebrated not as the achievement of the elite disabled athletes, but the 'transgress[ion of] the taboo boundary between blood, sweat, and tears, and blood, sweat and gears $^{127}$, very similar to the emphasis of the motor vehicle in motor sports. It is then questionable, as to whether the Paralympic Games is effective in empowering disabled athletes, or reinforces the 'disability' in sports with the preeminence of prothesis technology.

Furthermore, the extent to which the Paralympic Games, as an elite sporting competition, is accessible to all disabled persons is still limited. Most glaringly, persons with mental health impairments and hearing impairments are not afforded separate disability classifications under the Paralympic Games. Such athletes are not able to compete at the Paralympic Games without falling under any other disability classifications, and are left to compete at other separate competitions such as Special Olympic World Games and the Deaflympics, which are not held in conjunction with the Olympic Games.

125 This is also known as the 'technocentric ideology' of the Paralympic Movement. See Howe (2011b).

${ }^{126}$ CAS 2008/A/1480, Oscar Pistorius v/ International Association of Athletics Federation (IAAF), Award of 16 May 2008, pp. 3-4.

127 Butryn (2003). 


\subsection{The Rights of Women with Disabilities at the Paralympic Games}

Article 6 of the CRPD reiterates the full and equal enjoyment of fundamental rights and freedom of disabled women and girls, and recognises the intersectional nature of discrimination faced by disabled women and girls. In fact, the UN Committee of the Rights of Persons with Disabilities acknowledged that despite equality as a fundamental human right, there is a clear lack of recognition of the rights of disabled women and girls ${ }^{128}$. The UN Committee of the Rights of Persons with Disabilities made specific references ${ }^{129}$ to the Convention of the Elimination of Discrimination Against Women ('CEDAW') ${ }^{130}$ and its General Recommendations ${ }^{131}$ on the discrimination against disabled women and girls on the basis of health under article 12 of CEDAW. In particular, the UN Committee of the Rights of Persons with Disabilities made a specific comment that on top of the basic factors necessary for economic growth and eradication of poverty, State Parties also have the positive obligation to ensure necessary measures are in place for 'the health and participation [of disabled women and girls] in politics, culture, and sports ${ }^{132}$, pursuant to article 6(2) of the CRPD.

It is interesting to note that since its inception in 1948, the Paralympic Games has always had female participants ${ }^{133}$, unlike the modern Olympic Games which only had male participants between 1896 and $1900^{134}$. Unlike the Olympic Games, there has not been any form of female exclusion in the participation at the Paralympic Games.

Nonetheless, female athlete representation at the Paralympic Games is still severely lacking in proportion, compared the male athlete representation. At 2016 Rio de Janeiro Summer Paralympic Games $^{135}$, there were only 1669 female athletes out of a total number of 4317 athletes, which is approximately $38.7 \%$ female participation. At the 2014 Sochi Winter Paralympic Games ${ }^{136}$, there

\footnotetext{
${ }^{128}$ Committee on Rights of Persons with Disabilities, General Comment No. 3 (2016) on Women and Girls with Disabilities, UN CRPDOR, UN Doc CRPD/C/GC/3 (25 November 2016) ('General Comment 3'), paras $7-8$ https://www.paralympic.org/the-ipc/history-of-the-movement. Accessed 26 June 2019.

134 (2019) Key dates in the history of women in the Olympic Movement. In: International Olympic Committee. https://www.olympic.org/women-in-sport/background/key-dates. Accessed 26 June 2019.

${ }^{135}$ Brittain (2018a), p. 147.

${ }^{136}$ Ibid, p. 146.
} 
were only 128 female athletes out of a total of 538 athletes, which is approximately $23.8 \%$ female participation. This is in comparison to the 2016 Rio de Janeiro Summer Olympic Games and 2014 Sochi Winter Olympic Games ${ }^{137}$, wherein there were approximately $45 \%$ and $40.3 \%$ female participation respectively.

The lower levels of female participation in the Paralympic Games may be due the lower opportunities for women's events at the Paralympic Games. However, there are certain sports in the Paralympic Games which do not have the female category, such as football 5-a-side and football 7a-side ${ }^{138}$, which offers 176 male athletes the opportunity to compete at the Paralympic Games. Even for mixed-gender sports in the Paralympic Games, like wheelchair rugby ${ }^{139}$ and sailing ${ }^{140}$, countries are keener to seed more male players than female players. In comparison to the statistics today, there are more equal female representation at the recent Olympic Games. For instance, at the 2016 Rio de Janeiro Summer Olympic Games and 2014 Sochi Winter Olympic Games ${ }^{141}$, there were approximately $47.4 \%$ and $50 \%$ women's events respectively.

While statistically the proportion of female sports to male sports at the Paralympic Games is not significantly disproportionate ${ }^{142}$, there are several disability classifications within certain sports which do not have female categories, which means there are less medals at stake for female competition than male competition. For example, despite the same nature of events within athletics being competed in the male and female categories at the 2016 Summer Paralympic Games, there were 81 medals at stake for women in athletics, compared to 96 medals for men. This is because there are certain events within athletics which only offer men's competition. Logically, this led to lower female participation ${ }^{143}$ at the 2016 Summer Paralympic Games. While the cuts by the IPC in the disability classifications in the female category are driven by the lack of participation in the reduced events at the Paralympic Games, these cuts do perpetuate further exclusion and 'reduced competitiveness ${ }^{144}$ because athletes falling under these categories are only left with the option of

${ }^{137}$ International Olympic Committee (2016) Factsheet: Women in the Olympic Movement.

${ }^{138}$ Women's Sports Foundation, Women in the Olympic and Paralympic Games: An Analysis of Participation, Leadership and Media Coverage, June 2017, p. 47.

${ }^{139}$ In 2016 Summer Paralympic Games, there were only $2.1 \%$ female participation in mixed-gender wheelchair rugby. See Ibid, p. 17.

${ }^{140}$ In 2016 Summer Paralympic Games, there were only $18.8 \%$ female participation in mixed-gender sailing. See Ibid, p. 36.

${ }^{141}$ International Olympic Committee (2016) Factsheet: Women in the Olympic Movement.

${ }^{142}$ In 2016 Summer Paralympic Games, there were 226 women's event, out of 528 events. See Women's Sports Foundation, Women in the Olympic and Paralympic Games: An Analysis of Participation, Leadership and Media Coverage, June 2017, p. 16.

143 There was a $39.2 \%$ female participation at the Athletics event at the 2016 Summer Paralympic Games. See Women's Sports Foundation, Women in the Olympic and Paralympic Games: An Analysis of Participation, Leadership and Media Coverage, June 2017, p. 35.

${ }^{144}$ Peers (2012). 
competing in higher classification groups, wherein these athletes may not have the ability to make the qualification standards.

While the lack of female participation in sports may be due to national policies on gender and disability, the lower levels of female participation may also be due to the lack of female representation in sports at the international sports administration level. In 2017, only $20 \%$ of the IOC Executive Board ${ }^{145}$ and the IPC Governing Board ${ }^{146}$ are female. In a report by the Institute of Diversity and Ethics in Sports ${ }^{147}$, it was revealed that there is an astonishing 'widespread gender inequality' in international sports administration. It is not feasible to be developing gender equality in sporting participation at the Olympic Games or the Paralympic Games when this is not yet achieved at the international sporting administration level.

Apart from the above environmental barriers faced by disabled women in sports, disabled women in sports often face societal and cultural barriers to their participation in sports ${ }^{148}$. These barriers serve to discourage disabled women from contact with sports activities from a young age, providing them fewer opportunities ${ }^{149}$ to develop skills and strength required for sporting competition at an elite level, such as the Paralympic Games. Like any female athletes, disabled female athletes have to contend with prevailing societal attitudes towards 'athleticism' and 'stereotypically masculine traits $^{150}$. Societal and cultural attitudes which places value on the 'aesthetics of physical perfection' may further discourage female disabled athletes from participation in elite sports ${ }^{151}$. These attitudes perpetuate unequal treatment and discrimination against disabled women and girls in sports.

On this note, it is pertinent to note that there is still no provision or regulation of intersex and transgender athletes and their participation in the Paralympic Games. This point on intersex and transgender athlete participation is relevant because it pertains to the fairness of female competition and the general empowerment of women and girls through sports. While intersex and transgender athletes generally have a legal gender that they relate to, there has been an ongoing discussion on the regulation of intersex and transgender athletes at the Olympics Games, due to the unfair level of blood testosterone in intersex and transgender athletes who compete in the female category. The

\footnotetext{
145 Women's Sports Foundation, Women in the Olympic and Paralympic Games: An Analysis of Participation, Leadership and Media Coverage, June 2017, p. 38.

${ }^{146}$ Women's Sports Foundation, Women in the Olympic and Paralympic Games: An Analysis of Participation, Leadership and Media Coverage, June 2017, p. 43.

${ }^{147}$ Lapchick R et al. (2016) Gender Report Card: 2016 International Sports Report Card on Women in Leadership Roles.

${ }^{148}$ Slocum et al. (2018).

${ }^{149}$ Brittain (2011d).

${ }^{150}$ Buysse and Borcherding (2010).

${ }^{151}$ Hargreaves (2013).
} 
IOC has regulations governing the participation of a narrow group of intersex athletes ${ }^{152}$ and transgender athletes ${ }^{153}$, and the IPC does not have any thus far. While the fairness of the said IOC Regulations may be challenged ${ }^{154}$, there ought to be parallel regulations governing intersex and transgender disabled athletes who compete in the female category at the Paralympic Games, especially if there is sufficient scientific evidence on the performance advantages afforded to athletes with higher levels of blood testosterone, as this may further discourage female participation at the Paralympic Games.

\section{Effectiveness of the Paralympic Games as a Means of Integration}

In toto, the Paralympic Games does have certain effectiveness as a means of integrating disabled persons into society structurally, wherein the said Games serve as a platform for elite sporting performance and participation in disability sports and an impetus for fundamental human rights for disabled persons to be realised, as well as socially as elite disabled athletes are empowered through participation. Nonetheless, the increasing emphasis on technology in the Paralympic Games, as well as the inherent separation of the Olympic Games and the Paralympic Games adversely work to further exacerbate 'disability' in disability sports. The limitations to the prevailing disability classification system further limits the fundamental rights of certain disabled persons to participate at the Paralympic Games, which is arguably the pinnacle of disability sports when conducted in conjunction with the Olympic Games. The media's portrayal of the Paralympic Games and its participants as 'supercrip' have further aggravated the use of disability as a social creation in a disabling society ${ }^{155}$, and elite disabled athletes are not afforded the recognition as elite athletes in their own rights.

As a major global event with the Olympic Games, the Paralympic Games provides a platform for elite sporting participation in disability sports for aspiring athletes, and acts as a catalyst for further

\footnotetext{
${ }^{152}$ International Olympic Committee (2012) IOC Regulations on Female Hyperandrogenism: Games of the XXX Olympiad in London, 2012.

153 International Olympic Committee (2015) IOC Consensus Meeting on Sex Reassignment and Hyperandrogenism.

${ }^{154}$ In 2016, IAAF amended its Hyperandrogenism Regulation to the IAAF Female Eligibility Classification Regulations (Athlete with Differences of Sexual Development) after its Hyperandrogenism Regulations were suspended by CAS. See CAS 2014/A/3759 Dutee Chand v. Athletics Federation of India (AFI) \& The International Association of Athletics Federations (IAAF), Award of 24 July 2015. Note that there is a current appeal to the Swiss Federal Tribunal on the reasonableness of the current IAAF Female Eligibility Classification Regulations (Athlete with Differences of Sexual Development). See CAS 2018/O/5794-6798, Mokgadi Caster Semenya and Athletics South Africa v International Association of Athletics Federation, Award of 30 April 2019; Associated Press Caster Semenya appeals testosterone ruling: 'The IAAF will not drug me'. In: latimes.com. https://www.latimes.com/sports/olympics/la-sp-caster-semenya-appealstestosterone-ruling-20190529-story.html. Accessed 3 June 2019.

${ }^{155}$ Pursuant to the social model of disability, disability is seen as a social creation, in contrast to the medical model which focuses on the impairment of a person. See Shakespeare (2013).
} 
structural development for disabled persons through the development of disability-specific and disability-sports-specific infrastructure. The Paralympic Games also allow elite disabled athletes the right and freedom to participate in sports, and the further realisation of other fundamental rights and freedom, such as equality and non-discrimination, personhood and legal capacity, and accessibility under the CRPD.

However, the inherent separation of the Paralympic Games from the Olympic Games has served to further highlight physical impairments in sports through the difference of treatment. The farreaching option of conducting Paralympic sports within the Olympics Games have been historically proffered and considered, but to no avail. A proposal ${ }^{156}$ was made to IOC for two (2) wheelchair events to be featured in the 2000 Summer Olympic Games with full medal status, and not an exhibition or demonstration event. The proposal was rejected for unknown reasons ${ }^{157}$, with a comment from Dick Pound, a Canadian IOC member, that 'Any exercise of distinctions requires discriminating. We [the Olympic Games] cannot be all things to all people ${ }^{158}$. Logistically, conducting Paralympic sports within the Olympic Games may be challenging as this would massively increase the duration of the Olympic Games in order to accommodate the increase in number of medal contention, and this may further exacerbate the falling viewership ${ }^{159}$ of the Olympic Games.

There is also an increase in the use and development of technology within the Paralympic Games, or the 'cyborgfication' of the Paralympic Games, acts, to a certain extent, as a point of distraction away from the recognition and value of elite disabled athletes. On one hand, the use of protheses and wheelchairs make sports accessible to disabled persons, yet on the other hand, the use and development of such equipment have vastly diluted the recognition of being an elite disabled athlete due to the emphasis on the said equipment.

The limited disability classification system in the Paralympic Games have also limited the participation of disabled persons in sports. Systematically, prospective disabled athletes with no recognised disability classification in the Paralympic Games will not be able to participate in the Paralympic Games, or reap the benefits associated with it, such as the development in infrastructure and enjoyment of fundamental rights and freedom found in sporting participation. Furthermore, the

\footnotetext{
${ }^{156} \operatorname{Legg}(2018)$.

${ }^{157}$ Ibid.

${ }^{158}$ Clark (1970)

${ }^{159}$ Molla R (2018) Olympics viewership is down, even as NBC pays more for the rights to air it. In: Vox. https://www.vox.com/2018/2/9/16975680/olympics-winter-2018-viewership-down-nbc-rights-pyeongchang. Accessed 28 June 2019.
} 
prevailing practice of combining categories in certain Paralympic sports also have the effect of reduced competition and discouraging athletes from participation.

In any event, participation in the Paralympic Games has also been limited for disabled women. Disabled women generally face intersectional discrimination and have to overcome more societal and cultural barriers in order to participate in sports. This issue is further worsened by the fact that there are less sports and medals for women in the Paralympic Games, which serve as a further deterrence for disabled women participation in sports. Disability sports, in general, is not as accessible at the grassroot level as sports in the Olympic Games, because of the prevalent medical care and technology, and disabled persons without power or privilege often face greater environmental barriers to participate in disability sports, especially at the Paralympic Games.

Perhaps the greatest dissuasion to the effectiveness of the Paralympic Games as a means of integration of disabled persons in to society is the media's use of 'supercrip' capabilities to promote the Paralympic Games, which has the unfortunate effect of reinforcing socially-constructed stereotypical perception of impairment in elite disability sport, emphasizing disability as a social creation in a disabling society ${ }^{160}$.

Nonetheless, with its flaws and limitations, the Paralympic Games, as part of a broader Paralympic Movement for inclusion and equality in sporting opportunities for disabled persons, is admitted to be adequately effective for the integration of disabled persons into society, because at its crux, the Paralympic Games forms part of a broader realisation of fundamental human rights for disabled persons, especially under the CRPD. Notwithstanding the above, improvement and adjustments can be made for better realisation of these fundamental human rights for disabled persons in elite sports.

\section{Next Steps for the Paralympic Games}

Even if there is no room for the Paralympic Games or Paralympic sports to be featured at the same time as the Olympic Games, there are still some steps which can be taken for the Paralympic Games to promote better realisation of fundamental human rights for disabled persons and further alleviate the impact of societal, cultural and environmental barriers faced by disabled athletes ${ }^{161}$.

On a broader social level, disability as a social concept can be eradicated by proper portrayal of disabled athletes in the media during the promotion of the Paralympic Games. Whether the Paralympic Games ought to be seen more as a sporting game, like the Olympic Games, or a cultural

${ }^{160}$ Pursuant to the social model of disability, disability is seen as a social creation, in contrast to the medical model which focuses on the impairment of a person. See Shakespeare (2013).

${ }^{161}$ Brittain (2011c). 
game to 'inspire', disabled athletes should not be portrayed as 'superhumans' based on their impairments as inspiration porn ${ }^{162}$, or 'cyborgs' based on the use of technology. It is argued by proponents ${ }^{163}$ that environmental barriers, such as public policies, faced by disabled persons can be incrementally removed if prevailing dominant perceptions of disability are changed, and it can begin with the media portrayal of the pinnacle game of disability sports. By proper portrayal of disability sports, not 'supercrip' mentality but viewing disabled athletes as athletes in their own rights, it will inevitably improve the current 'disablist values' within society and 'institutional structures' within which disabled persons are forced to operate within ${ }^{164}$.

The eradication of eugenic remnants towards disability is another step which can be taken for the Paralympic Games to be a more effective means for the integration of disabled persons into society. Elite sports, in general, is exclusionary in nature and inherently embodies certain eugenic traits and beliefs. The first recorded writing on eugenic practices was during the time of the ancient Olympic Games (even though it was not coined as 'eugenics' until 1883 by Francis Galton ${ }^{165}$ ) by Plato, in The Republic ${ }^{166}$. Fundamentally, the ancient Olympic Games were founded upon exclusive terms ${ }^{167}$ based on distinction in sporting performance. This feature of the Olympic Games was adopted by Baron Pierre du Coubertin when he revived the Olympic Games and 'Olympism', which to him meant 'an aristocracy, an elite ${ }^{, 168}$. Even though Baron Coubertin did not share the same visions of utopia like their socialist counterparts, Baron Coubertin held deep beliefs towards 'proto-totalitarian concepts', such as eugenics and moral hygiene ${ }^{169}$. Baron Coubertin held innate beliefs on the exclusion of 'non-whites' or 'savages' 170 from the elitist and noble meeting of the modern Olympic Games. James Edward Sullivan, who was the president of the Amateur Athletics Union from 1906 to 1909 , proposed ${ }^{171}$ to have a 'Special Olympics' for the non-whites, to dispel any conception that the non-whites could compete at the same level as the Caucasians. Even Adolf Hitler attempted to use the 1936 Berlin Summer Olympic Games to showcase the 'supremacy' of the Aryan race. Furthermore, the revival of the Olympic Games was incorporated into a prevailing ideological

\footnotetext{
162 Young S (2014) I'm not your inspiration, thank you very much.

${ }_{163}$ Morris (1991); Devine (1997).

${ }^{164}$ Imrie (1997).

165 Galton (1883).

166 Galton (1998).

${ }^{167}$ Participants in the ancient Games had to be men or boys who is a member of a Greek state, belongs to a tribe, has a father and family, and is free and not illegitimate. See Crowther (1996).

${ }^{168}$ Boykoff (2016), p. 13.

${ }^{169}$ Berg (2008).

${ }^{170}$ Schantz (2008).

${ }^{171}$ Boykoff (2016).
} 
system, which was determined by Greek nationalism, which embodied the 'biologizing approach to athleticism ${ }^{172}$ and unfortunately, eugenics.

These embedded eugenic beliefs within elite sports may also be a factor in the lack of representation and participation of disabled women in the Paralympic Games. In the early years of the modern Olympic Games, Baron Coubertin excluded women from participating in the Olympic Games based

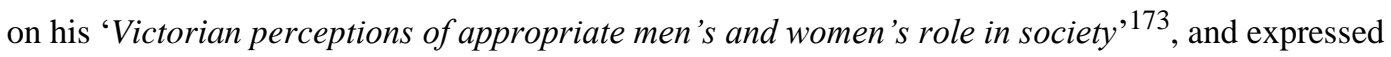
his disapproval towards 'the indecency ugliness, and impropriety of women' in sports, wherein women engaging in strenuous activities like sports 'destroy their feminine charm' 174 .

Nonetheless, it must be admitted that the eradication of eugenic beliefs in elite sports, which is inherently exclusionary and based on distinction, would be challenging, if not almost impossible without compromising the essence of sports. At the outset, the establishment of the ancient Olympic Games was based on distinction of physical ability and skills for national prestige ${ }^{175}$. The whole process of elite and competitive sports, from hard-hitting training sessions to stringent selection processes, is high performance, and by extension, athletes would employ any (hopefully, legitimate) strategies or methods to enhance and maximise their performance. There is an inherent, unresolvable contradiction between the culture of inclusion pursued by the IPC and the exclusive nature of elite sports competition ${ }^{176}$.

There have been certain alternatives presented as to how the Paralympic Games can develop to further integrate disabled persons into society. Legg, Fay, Hums and Wolff ${ }^{177}$ examined wheelchair disability sports in the Olympic Games and proffer certain alternatives to the system, amongst which is integrating the medal tally for the Olympic Games and the Paralympic Games, and have Exhibition Games at the Olympic Games for disability sporting competition with Paralympic Games medals. These alternatives would naturally elevate the Paralympic Games to certain prominence and political interest, and a positive step toward inclusion and valuing diversity ${ }^{178}$. In particular, Legg, Fay, Hums and Wolff recommended that the events at both the Olympic Games and Paralympic Games be considered equal medals towards medal count. This recommendation may have certain effectiveness in influencing states to recognise disability sports and invest into infrastructure therein. To build on this recommendation for equal medal count, it may be worth considering swapping the

\footnotetext{
172 Koulouri C (1896) The First Modern Olympic Games at Athens, 1896 in the European Context.

${ }^{173}$ Borish (1996).

${ }_{174}$ Mitchell (1977).

${ }^{175}$ Crowther (1996)

${ }^{176}$ Howe (2011a).

${ }^{177}$ Legg et al. (2009).

${ }^{178}$ Fay TG (2000) Race, gender, and disability: A new paradigm towards full participation and equal opportunity in sport. University of Massachusetts Amherst.
} 
sequence of the Olympic Games with the Paralympic Games, wherein countries with greater emphasis on disability sports will benefit from higher starting medal count at the Olympic Games.

Further work can also be done to develop the disability classification system for the Paralympic Games. Notwithstanding other issues to the prevailing disability classification system, specifically, there has to be greater representation of the various disabilities recognised by WHO, at sports at the Paralympic Games, which is the only disability sporting competition held in 'parallel' with the Olympic Games. Certain major impairment groups, such as mental health impairments and hearing impairments ought to be given disability classifications at the Paralympic Games. Athletes with hearing disabilities may require different equipment for competition i.e. light or tactile, but they ought to be afforded the same recognition and platform for elite competition at the Paralympic Games.

Team sports can also widen its scope of participation by including other forms of disability, apart from just wheelchair sports. And finally, IPC should avoid eliminating certain disability categories due to the lack of participants, or the lack of audience interests and appeal. Apart from alleviating the impact of reduced competitiveness of athletes in eliminated categories, providing the athletes the opportunity to compete at the Paralympic Games will buttress their fundamental right to sports.

The Paralympic Games can also adopt the concept of 'Unified Sports' from the Special Olympics Unified Sports programme, which brings athletes with and without intellectual disabilities together for team sports. While the Special Olympics Unified Sports are still not a feature of the Special Olympics World Games, the impact ${ }^{179}$ of unified team sports on the social perception of persons with intellectual disabilities and psycho-social impact on the disabled athletes are optimistic. Unlike disability classifications consisting of equipment such as wheelchairs and prosthesis, there is lesser safety concerns involving other able-bodied athletes to join team sports for persons with intellectual disabilities. Currently, there are no team games for athletes with intellectual disabilities at the Paralympic Games, and introducing unified team sports to athletes with intellectual disabilities at the Paralympic Games has the potential to raise the profile and competitiveness at the said Games.

Another recommendation to promote representation and participation is the introduction of the wild card system to countries which do not have athletes who have qualified for the various editions of the Paralympic Games. This equivalent system at the Olympic Games is also known as the 'Unqualified NOC', wherein countries are allowed to send unqualified athletes (with the wild card) to the Olympic Games for particular sports (such as athletics) if there are no athletes in the country who have met the qualifying mark for the said sports. This wild card system will serve as an impetus

${ }^{179}$ Castagno (2001); McConkey et al. (2013); Özer et al. (2012). 
for countries at the early stages of developing their disability sport ecosystem, wherein their athletes will still be able to participate at the pinnacle disability sport to gain valuable exposure and network. A wild card system which provides opportunity to female athletes i.e. one male and female wild card, can also serve to benefit countries will little emphasis on female representation in disability sports.

Steps can also be taken to promote and strengthen unionisation of disabled athletes, just like ablebodied athletes, and eventually move to the collective bargaining by agents and/or unions. Unionisation is a crucial step for professional athletes to realise their fundamental rights and freedom as professional athletes, and collective bargaining provides athletes a stronger voice and bargaining power to negotiate for their entitled rights and freedom. In particular, article 6 of the UDPR provides that all players have the right to 'organise and collectively bargain and to form and join player and athlete associations and unions for the protection of his or her interest ${ }^{180}$.

Such unionisation is not yet prominent in disability sport. For instance, the Union of Players' Rights do not yet include elite disabled athletes. Furthermore, the World Player Rights Policy makes no mention to all international human rights treaty except the CRPD. IPC can take steps to promote the establishment and influence of unions. For example, FIFA set up FIFPro in 1965 as a unionising voice for association football players, in order to promote the development of unions. Now, the influence of unions in association football is arguably one of the strongest union movement in professional sports.

The use of the Paralympic Games as an impetus for the integration of disabled persons into society can be more efficient if there is better engagement of the public during the Paralympic Games. It is trite that in most countries, the Paralympic Games receive less coverage than the Olympics Games. It was recorded that BBC gave 540 hours of showing time on television to the Sydney Olympic Games and only around 12 hours for the Sydney Paralympic Games ${ }^{181}$. The showing time afforded to the Paralympic Games is indicative of the value placed by programmers on the said Games, but such limited showing time exacerbates the global lack of exposure of the Paralympic Games. There has been improvement in the media coverage of the Paralympic Games since 2000 Sydney Paralympic Games, especially with the launch of the internet-based free view television source, at www.ParalympicSport.TV, since 2006. More work to can also be done to market the Paralympic brand to advance the exposure of the Paralympic Games. In particular, certain work ought to be done to work on the sudden drop of engagement when the Paralympic Games end ${ }^{182}$, but instead

\footnotetext{
${ }^{180}$ World Players Association (2017) Universal Declaration of Player Rights.

${ }^{181}$ Brittain (2002)

${ }^{182}$ Molesworth et al. (2015).
} 
ride on the waves of exposure created by each Paralympic Games, for the further promotion and integration of disabled persons into society.

\section{Conclusion}

In general, the Paralympic Games does not just increase the visibility and participation in disability sport in society, the Paralympic Games does support the inclusion and integration of disabled persons into society and promotes the realisation of fundamental human rights and freedom afforded to disabled persons set out in the CRPD and the various other core human rights treaties. The Paralympic Games provides an effective platform for elite sporting participation in disability sports for aspiring athletes, and acts as a catalyst for further systematic development for disabled persons through the development of disability-specific and disability-sports-specific infrastructure. Nonetheless, this paper also makes clear that there are severe limitations to the participation and representation of disabled athletes in the Paralympic Games, from the limitations to the disability classifications at the said Games, and the inaccessibility of disability sport by disabled persons without power or privilege. The role of the media in the promotion of the Paralympic Games also reinforces stereotypes of impairments, buttressing a disabling culture, instead of recognising elite disabled athletes as elite athletes in their own rights. The inherent contradiction between the inclusive culture that the IPC is pursuing, and the exclusive nature of elite sports is unresolvable as a quagmire. Even if eugenics remnants of the Olympic Games and culture can be eradicated, elite sports may always be exclusive, which is probably what elite athletes with disabilities are seeking for.

In any event, this paper only seeks to address the effectiveness of the Paralympic Games on the integration of disabled persons into society. There is still a huge gap between how athletes at the Paralympic Games are perceived and how the rest of the disabled community is seen ${ }^{183}$. The pursuit of an elite athlete with disabilities is very different from an everyday life of a disabled person, wherein there is greater interest in education, employment, health, housing and transport ${ }^{184}$.

${ }^{183}$ Christiansen S (2013) A year after the Paralympics attitudes to disability needs to improve | Sophie Christiansen. The Guardian.

${ }^{184}$ Barnes (1991); Barnes et al. (2005). 


\section{7. $\quad$ References}

Adnan Y, McKenzie A, Miyahara M (2001) Self-Efficacy for Quad Rugby Skills and Activities of Daily Living. Adapted Physical Activity Quarterly 18:90-101

Ahmed N (2013) Paralympics 2012 Legacy: Accessible Housing and Disability Equality or Inequality? Disability \& Society 28:129-133. https://doi.org/10.1080/09687599.2012.739367

Barnes C (1991) Disabled people in Britain and discrimination: A case for anti-discrimination legislation. C. Hurst \& Co. Publishers

Barnes C, Mercer G, Shakespeare T (2005) Exploring Disability: A Sociological Introduction. Cambridge: Polity Press

Berg C (2008) Politics, Not Sport, is the Purpose of the Olympic Games. The Institute of Public Affairs Review: A Quarterly Review of Politics and Public Affairs 60:15-18

Bertling C, Schierl T (2008) Disabled Sport and its Relation to Contemporary Cultures of Presence and Aesthetics. Sport in History 28:39-50. https://doi.org/10.1080/17460260801889202

Borish LJ (1996) Women at the Modern Olympic Games: An Interdisciplinary Look at American Culture. Quest 48:43-56. https://doi.org/10.1080/00336297.1996.10484177

Boykoff J (2016) Power Games: A Political History of the Olympics. Verso Books

Brittain I (2002) Elite athletes with disabilities: problems and possibilities. Unpublished $\mathrm{PhD}$ thesis Buckinghamshire Chilterns University College, UK

Brittain I (2011a) Introduction. In: The Paralympic Games Explained. Taylor \& Francis Group, pp $1-5$

Brittain I (2011b) Media, Marketing and Disability Sports. In: The Paralympic Games Explained. Routledge, pp 86-111

Brittain I (2011c) Major Issues within the Paralympic Movement. In: The Paralympic Games Explained. Routledge, Oxford, pp 91-105

Brittain I (2011d) The Under-Representation of Women and Athletes With High Support Needs at the Paralympic Games. In: The Paralympic Games Explained. pp 106-121

Brittain I (2018a) Key Points in the History and Development of the Paralympic Games. In: The Palgrave Handbook of Paralympic Studies. Palgrave Macmillan, London, United Kingdom, pp 125150

Brittain I (2018b) The Paralympic Movement and the Boycott Agenda: South Africa, Apartheid and the Paralympic Games. In: The Palgrave Handbook of Paralympic Studies. Palgrave Macmillan, London, United Kingdom, pp 321-344

Brittain I, Wolff E (2007) Why Language Matters. Pittsburgh, Illinois

Burton M, Fuss FK, Subic A (2010) Sports wheelchair technologies. Sports Technology 3:154-167. https://doi.org/10.1080/19346182.2011.564286 
Butryn TM (2003) Posthuman podiums: Cyborg narratives of elite track and field athletes. Sociology of Sport Journal 20:17-39

Buysse JAM, Borcherding B (2010) Framing Gender and Disability: A Cross-Cultural Analysis of Photographs from the 2008 Paralympic Games. International Journal of Sport Communication 3:308-321. https://doi.org/10.1123/ijsc.3.3.308

Campbell E, Jones G (1994) Psychological Well-Being in Wheelchair Sport Participants and Nonparticipants. Adapted Physical Activity Quarterly 11:404-415

Casini L (2011) The making of a lex sportiva by the Court of Arbitration for Sport. German Law Journal 12:1317-1340

Castagno KS (2001) Special Olympics Unified Sports: Changes in Male Athletes During a Basketball Season. Adapted Physical Activity Quarterly 18:193-206

Clark J (1970) Fifth wheels: The XXV Olympiad is the XXVth to exclude disabled jocks. Village Voice 1:

Crow L (2014) Scroungers and superhumans: Images of disability from the summer of 2012: A visual inquiry. Journal of visual culture 13:168-181

Crowther NB (1996) Athlete and State: Qualifying for the Olympic Games in Ancient Greece. Journal of Sport History 23:34-43

Darcy S (2003) The politics of disability and access: the Sydney 2000 Games experience. Disability \& Society 18:737-757

Darcy S (2018a) The Paralympic Movement: A Small Number of Behemoths Overwhelming a Large Number of Also-Rans-A Pyramid Built on Quicksand? In: The Palgrave Handbook of Paralympic Studies. Palgrave Macmillan, London, United Kingdom, pp 221-246

Darcy S (2018b) Accessibility as a Key Management Component of the Paralympics. In: Managing the Paralympics. Palgrave Macmillan, London, United Kingdom, pp 49-92

Davis RW, Ferrara MS (1996) Athlete classification: An explanation of the process. Paleastra

De Bosscher V, De Knop P, Van Bottenburg M, Shibli S (2006) A Conceptual Framework for Analysing Sports Policy Factors Leading to International Sporting Success. European Sport Management Quarterly 6:185-215. https://doi.org/10.1080/16184740600955087

Devine MA (1997) Inclusive leisure services and research: a consideration of the use of social construction theory. Journal of Leisurability 24:3-11

Dickson TJ, Darcy S, Johns R, Pentifallo C (2016) Inclusive by design: transformative services and sport-event accessibility. The Service Industries Journal 36:532-555. https://doi.org/10.1080/02642069.2016.1255728

Flynn E, Arstein-Kerslake A (2014) Legislating personhood: Realising the right to support in exercising legal capacity. International Journal of Law in Context 10:81-104

Galton DJ (1998) Greek theories on eugenics. Journal of Medical Ethics 24:263-267. https://doi.org/10.1136/jme.24.4.263

Galton F (1883) Inquiries into human faculty and its development. Macmillan, London 
Golden A (2003) An Analysis of the Dissimilar Coverage of the 2002 Olympics and Paralympics: Frenzied Pack Journalism versus the Empty Press Room. Disability Studies Quarterly 23:. https://doi.org/10.18061/dsq.v23i3/4.437

Guttmann L (1952) On the Way to an International Sports Movement for the Paralysed. The Cord $5: 7-23$

Hargreaves J (2013) Heroines of sport: The politics of difference and identity. Routledge

Howe D (2011a) Sociology. In: Handbook of Sports Medicine and Science, the Paralympic Athlete. Wiley Blackwell, Oxford, pp 102-115

Howe PD (2011b) Cyborg and Supercrip: The Paralympics Technology and the (Dis)empowerment of Disabled Athletes. Sociology 45:868-882. https://doi.org/10.1177/0038038511413421

Imrie R (1997) Rethinking the relationships between disability, rehabilitation, and society. Disability and rehabilitation 19:263-271

Karageorgos AF, Higgs C (2018) The Paralympic Movement and the International Development Agenda. In: The Palgrave Handbook of Paralympic Studies. Palgrave Macmillan, London, United Kingdom, pp 273-294

Kerr S (2018) The London 2012 Paralympic Games. In: The Palgrave Handbook of Paralympic Studies. Palgrave Macmillan, London, United Kingdom, pp 481-505

Legg D (2018) Development of the IPC and Relations with the IOC and Other Stakeholders. In: The Palgrave Handbook of Paralympic Studies. Palgrave Macmillan, London, United Kingdom, pp 151172

Legg D, Fay T, Hums MA, Wolff E (2009) Examining the Inclusion of Wheelchair Exhibition Events within the Olympic Games 1984-2004. European Sport Management Quarterly 9:243-258. https://doi.org/10.1080/16184740903023997

Martin J, Wheeler G Psychology. In: The Paralympic Athlete. Wiley Blackwell, West Sussex, UK, pp 118-121

Martin JJ (1999) Predictors of Social Physique Anxiety in Adolescent Swimmers with Physical Disabilities. Adapted Physical Activity Quarterly 16:75-85. https://doi.org/10.1123/apaq.16.1.75

McConkey R, Dowling S, Hassan D, Menke S (2013) Promoting social inclusion through unified sports for youth with intellectual disabilities: a five-nation study. Journal of intellectual disability research 57:923-935

McLaren RH (2000) The Court of Arbitration for Sport: An Independent Arena for the World's Sports Disputes. Valparaiso University Law Review 35:379-405

Miller P, Parker S, Gillison S (2004) Disablism: How to Tackle the Last Prejudice. Demos, London

Misener L, Molloy K (2018) Organising and Delivering the Modern Paralympic Games: Contemporary Debates Relating to Integration and Distinction. In: The Palgrave Handbook of Paralympic Studies. Palgrave Macmillan, London, United Kingdom, pp 197-220

Mitchell S (1977) Women's Participation in the Olympic Games 1900-1926. Journal of Sport History 4:208-228 
Molesworth M, Jackson D, Scullion R (2015) Where agendas collide: Online talk and the Paralympics. In: Reframing disability: Media, (Dis)Empowerment, and Voice in the 2012 Paralympics. pp 123-137

Morris J (1991) Pride against prejudice: A personal politics of disability. Women's Press London

Oliver M (1990) The politics of disablement. Palgrave Macmillan, Basingstoke

Özer D, Baran F, Aktop A, et al. (2012) Effects of a Special Olympics Unified Sports soccer program on psycho-social attributes of youth with and without intellectual disability. Research in developmental disabilities 33:229-239

Peers D (2012) Patients, Athletes, Freaks: Paralympism and the Reproduction of Disability. Journal of Sport and Social Issues 36:295-316. https://doi.org/10.1177/0193723512442201

Purdue DE (2013) An (in) convenient truce? Paralympic stakeholders' reflections on the OlympicParalympic relationship. Journal of sport and social issues 37:384-402

Rocco TS, West GW (1998) Deconstructing Privilege: An Examination of Privilege in Adult Education. Adult Education Quarterly 48:171-184. https://doi.org/10.1177/074171369804800304

Schantz OJ (2008) Pierre de Coubertin's" civilizing mission". In: Proceedings: International Symposium for Olympic Research. International Centre for Olympic Studies, pp 53-63

Shakespeare T (2013) The Social Model of Disability. In: The Disability Studies Reader, 4th ed. Routledge, New York, NY, pp 214-221

Silva CF, Howe PD (2012) The (in) validity of supercrip representation of Paralympian athletes. Journal of Sport and Social Issues 36:174-194

Slocum C, Kim S, Blauwet C (2018) Women and Athletes with High Support Needs in Paralympic Sport: Progress and Further Opportunities for Underrepresented Populations. In: The Palgrave Handbook of Paralympic Studies. Palgrave Macmillan, London, United Kingdom, pp 371-388

Stein MA (2017) Disability human rights. In: Nussbaum and Law. Routledge, pp 3-49

Swartz L, Bantjes J, Knight B, et al. (2018) "They don't understand that we also exist": South African participants in competitive disability sport and the politics of identity. Disability and Rehabilitation 40:35-41. https://doi.org/10.1080/09638288.2016.1242171

Swartz L, Hunt X, Bantjes J, et al. (2019) Mental health symptoms and disorders in Paralympic athletes: a narrative review. British Journal of Sports Medicine 53:737-740. https://doi.org/10.1136/bjsports-2019-100731

Tweedy SM, Howe D (2011) Introduction to the Paralympic Movement. In: The Paralympic Athlete. Wiley Blackwell, West Sussex, UK, pp 1-30

Tweedy SM, Vanl YC (2009) International Paralympic Committee Position Stand - Background and scientific principles of Classification in Paralympic Sport. British Journal of Sports Medicine 45:259-269. http://dx.doi.org/10.1136/bjsm.2009.065060 


\section{University Library}

\section{- M M N E R VA A gateway to Melbourne's research publications}

Minerva Access is the Institutional Repository of The University of Melbourne

Author/s:

Goh, CL

Title:

To what extent does the Paralympic Games promote the integration of disabled persons into society?

Date:

2020-02-27

\section{Citation:}

Goh, C. L. (2020). To what extent does the Paralympic Games promote the integration of disabled persons into society?. International Sports Law Journal, 20 (1-2), pp.36-54. https:// doi.org/10.1007/s40318-020-00164-w.

Persistent Link:

http://hdl.handle.net/11343/265892 